\title{
Suvremena recepcija Ciceronove prirodnopravne postavke o vrhovnosti dobrobiti i spasa naroda u kontekstu izvanrednih stanja aktualiziranih pandemijom COVID-19
}

\author{
TOMISLAV NEDIĆ
}

Akademija za umjetnost i kulturu, Sveučilište J.J. Strossmayera u Osijeku

\begin{abstract}
Sažetak
U radu se nudi interpretativna analitika i recepcija Ciceronove tvrdnje o imperativnoj supremaciji dobrobiti i spasa naroda (salus populi suprema lex esto), izrečenoj u trećoj knjizi Ciceronovih Zakona. Navedena je tvrdnja samo djelić cjelokupnog "mozaika" Ciceronove državno-pravne misli koja je dobrim dijelom bila orijentirana prema reparaciji i opstojnosti Rimske republike, čiji historijski kontekst ukazuje na mnogobrojne nedaće koje su utjecale na njezin integritet. Potrebno je prije svega ponuditi interpretativni presjek Ciceronove tvrdnje o vrhovnosti dobrobiti i spasa naroda i republike u historijskom kontekstu tadašnjih rimskih političkih i pravnih prilika kako bi se stekao kompletan uvid na koji je način ta tvrdnja nadalje bila recipirana, osobito u suvremenoj (ustavno)pravnoj doktrini i praksi. Ozbiljenje Ciceronove tvrdnje $\mathrm{u}$ vidu ustavnih odredbi (čl. 16., 17. i 101. Ustava RH) o izvanrednim i kriznim stanjima postala je aktualna pojavom pandemije COVID-19, ali se oko nje stvaraju i nove kontroverzije, što je pokazala i kazuistička analiza određenih recentnih odluka Ustavnog suda Republike Hrvatske.
\end{abstract}

Ključne riječi: Ciceron, salus populi, suprema lex, ustav, prirodno pravo, res publica, COVID-19

\section{Uvod}

Odveć turbulentan historijski kontekst političkih prilika u zadnjim trenucima Rimske republike bio je od presudne uloge $u$ formiranju kompletnog stvaralaštva državno-pravne misli Marka Tulija Cicerona. I sam je Ciceron u brojnim zapisima razmatrao odrednice filozofije povijesti, koju označava "svjedokom vremena, svjetlom istine, životom pamćenja, učiteljicom života i glasnicom starine" (Ciceron, 2002, 
str. 123). Kao suvremenik mnogobrojnih nedaća koje su utjecale na sudbinu Rimske republike, urota, atentata, građanskih ratova i kršenja rimskog javnopravnog poretka od najviših državnih dužnosnika, Ciceron na kritički način razmatra sve navedene opasnosti, javno upozoravajući na njih radi zaštite opstojnosti Republike, zbog čega naposljetku biva i usmrćen u kontroverznim proskripcijama od dionika drugog trijumvirata, osobito utjecajem Marka Antonija. U tom se pogledu reflektira izuzetnost Ciceronovog promišljanja koje se sastojalo od uzastopnog (akademsko-)skeptičkog propitkivanja i neprihvaćanja onog apsolutnog te onoga zadanog rimskim političkim prilikama i njezinim akterima. Pragmatični je duh Cicerona, kao vrsnog političara, zastupnika (odvjetnika) i govornika koji je vlastitu misao itekako dobro prezentirao, dolazio do izražaja u gotovo svim njegovim zapisima.

Možebitno je čak kako se Ciceronu kao mislitelju i ne daje dovoljno pozornosti u pravnofilozofskoj i političkofilozofskoj misli općenito jer bi ga se moglo smatrati samo interpretatorom i "transplantatorom" grčke misli, osobito ideja iz Platonove

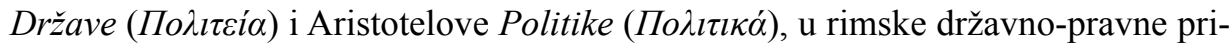
like, odnosno eklektikom koji u filozofsku misao ne unosi ništa dotada neviđeno. Međutim, ako se Ciceron čak i kategorički označi eklektičarem, takva činjenica nikako ne doprinosi zaključku kako je njegova misao ostala nezapaženom i, ugrubo rečeno, nebitnom u političko-pravnoj misli općenito. Razradom Ciceronove misli bavile su se utjecajne persone političke i pravne misli poput Laktancija, Augustina, Hobbesa, Lockea, Miltona, Humea, Rousseaua, Montesquiea i drugih ( $c f$. Sellers, 2009).

Država bez zakona ne može se smatrati državom, pa se tako, baš poput Platona

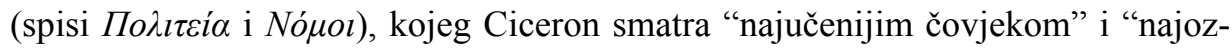
biljnijim filozofom" te čiji primjer slijedi, doslovnost atributa "državno-pravna" (u cjelini sintagme uz riječ "misao") najbolje reflektira upravo u Ciceronovoj misli:

Ali kao što je postupio najučeniji čovjek, Platon, ujedno najozbiljniji od svih filozofa, koji je prvi sastavio spis o državi i isto tako zaseban o njezinim zakonima, mislim da i ja, prije nego što kažem riječi zakona, moram reći nešto u obranu toga zakona. Vidim da su isto učinili Zaleuk i Charonda, a oni svojim gradovima nisu napisali zakone radi teorije ili zabave, nego radi države. (Ciceron, 1996, str. 64).

Glavni je temelj Ciceronove političke i pravne filozofije sadržan u dva njegova spisa koji zajedno čine neraskidivu cjelinu - Država (De re publica) i Zakoni (De legibus). U prvom Ciceron, na tragu već spomenute Platonove Države i Aristotelove Politike, razrađuje koncept idealne države, koja to postaje zahvaljujući pomno konstruiranoj legislativi čija se ideja i koncepcija nude u Zakonima. Glavni cilj Zakona jest upravo razrada idealne države elaborirane u Državi (cf. Wood, 1988, str. 67). No Ciceronovo filozofsko stvaralaštvo u sferi državno-pravne teorije ni- 
je moguće vakuumski promatrati samo u vidu spisa Države i Zakona. Ciceronova moralna filozofija o dužnostima i vrlinama iznesena u Dužnostima (De officiis) i Krajnostima dobra i zla (De finibus bonorum et malorum), kao i rasprave o retoričkom umijeću magistrata u Govorniku (De oratore), uvelike determiniraju kompletno Ciceronovo shvaćanje biti države i prava te svih njihovih elemenata. Jer koncept Ciceronove države temelji se na mješovitom ustavu koji državu stavlja u ravnotežu između monarhije, aristokracije i demokracije, uz sveopće postojanje onih zakona koji, na stoičkom tragu, počivaju na ideji pravednosti i prirodnog prava utemeljenog na razumu, podarenog od bogova, ${ }^{1}$ a koju filozofski školovani vladar pravilnih moralnih prosudbi i izuzetnih govorničkih vještina prilagođava društvu u kojem obitava. Ciceron takav koncept bazira na Polibijevom konceptu mješovitog ustava, ali uz određene razlike, pragmatički ga prilagođavajući rimskim prilikama (cf. Asmis, 2005). Problematika rimskog ustava općenito prije svega se bazira na pitanju možemo li uopće govoriti o ustavu u današnjim shvaćanjima navedenog pojma (o navedenome više u Straumann, 2011) ili više u smislu koncepta vlasti i političke organizacije (Asmis, 2005), lat. status civitatis (Ciceron, 1995, str. 45) te status rei publicae (ibid., str. 53) ?² Tako Ciceron tvori koncept mješovitog ustava zasnovan na prirodnopravnim temeljima. Gugg navodi kako je upravo središte Ciceronovog političkog mišljenja, zemaljsko-realna vječnost (dinamična vječnost zasnovana na moralnoj snazi koja se iznova obnavlja jer "država mora trajati vječno"; 3 ibid., str. 160) pravedne države (Rima), u vidu stremljenja da sačuva neusporedivi ustav kao življenu zbilju i u duhu pravednosti ispuni one zadaće koje mu se postavljaju, jer je, prema Ciceronu, glavna opasnost za svjetsko carstvo kao što je Rim upravo unutarnja kriza koja je uvijek deficit pravednosti (Gugg, 1998, str. 76). Navedena se kriza može nadomjestiti isključivo pravednošću (kao najvišom vrlinom), pa i sam Ciceron djelovanje u izvanrednim okolnostima temelji na izvan-pravnom postupanju (suprema lex) izvršne vlasti, što čini otklon od suvremene ideje da su instituti izvanrednih stanja izgrađeni na postavci da ih se mora urediti sustavom prava (vidjeti infra), bez mogućnosti djelovanja extra legem.

1 "Zato su taj prvi i krajnji zakon nazivali umom boga koji mudrošću uvijek sili i zabranjuje. Zbog toga s pravom hvale onaj zakon koji su bogovi dali ljudskom rodu, jer je on um i razum mudroga, moćan naređivati i odvraćati” (Ciceron, 1996, str. 60).

${ }^{2}$ Kada se govori o rimskom ustavu, govori se o onom ustavu koji nije bio formalan i kodificiran, ali koji je, prema Fontanelli (2013), bio temelj Rimske republike i prije nego ga je Ciceron predstavio u Državi i Zakonima (tako i Mantovani, 2016, str. 30). Tako će Scipion u Državi: “Držim naime, mislim, tvrdim, da nijedna od svih država ni po ustavu (constitutione) ni po poretku ni po stezi nije usporediva s onom koju su naši očevi primili od predaka i ostavili je nama" (Ciceron, 1995, str. 78).

${ }^{3}$ Upravo ideja o vječnosti države temelj je ideje "o nadmoći države nad važenjem pravne norme” (Schmitt, 2019, str. 19) kao ishodištu državnog centrizma. 
Iako su sam Ciceron, kao pater patriae, i njegovo djelo primarno bili orijentirani boljitku rimskog naroda i republike, u nekoliko navrata u Zakonima svojemu sugovorniku Attiku napominje kako mu nije namjera ponuditi ona rješenja (zakone) koja kategorički doprinose općoj dobrobiti rimskog naroda, već "svima dobrim i čvrstima narodima" (omnibus bonis firmisque populi; Ciceron, 1996, str. 86) "koji uzimaju da vrijedi tražiti sve što je časno i pravilno samo po sebi”, sa svrhom "jačanja država, učvršćivanja gradova i ozdravljenja naroda" (ibid.). Pa tako baš u Zakonima Ciceron utvrđuje tezu o dobrobiti i spasu naroda, odnosno same republike (salus populi/rei publicae), koji se imperativno imaju postaviti (esto) najvišim zakonom (suprema lex). U suvremenoj se ustavnopravnoj i državnopravnoj doktrini implementacija Ciceronove maksime treba primarno promatrati u kontekstu zaštite opstojnosti države i naroda u tzv. izvanrednim situacijama; to je stavlja pred velike izazove uzrokovane epidemijom COVID-19, kao i, u tuzemnim prilikama promatrajući, nezapamćenim katastrofalnim razmjerima uzastopnih potresa u područjima središnje Hrvatske. Slijedom navedenih činitelja, Ciceronova maksima postaje aktualna i možebitno se ozbiljuje u vremenima koja dovode u pitanje cjelokupno funkcioniranje društva. Interpretacija navedene Ciceronove maksime nikako se ne može provesti parcijalno, netemeljito i olakotno, već isključivo uz detaljno propitkivanje mnogobojnih čimbenika koji emaniraju iz sinergijskog postava različitih spoznajnih perspektiva iz sfere političke i pravne filozofije, političke povijesti, rimskog javnog i privatnog prava, državno-pravne teorije i ustavnog prava.

S obzirom na kompletno izneseni postav, cilj se rada, konceptualno podijeljenog u dva osnovna dijela, ogleda u pokušaju interpretativne analitike Ciceronove tvrdnje o supremaciji dobrobiti naroda i države te elaboracije načina njezine recepcije u suvremenim ustavnopravnim porecima, s isključivim osvrtom na hrvatski. U prvom se dijelu interpretativno i analitički razrađuje Ciceronova tvrdnja salus populi suprema lex esto, iznesena u trećoj knjizi Zakona, s obzirom na tadašnje povijesne, točnije pravne i političke prilike Rimske republike, ali i kompletnu Ciceronovu filozofsku misao. $U$ drugom se dijelu analizira daljnja recepcija te tvrdnje u hrvatskim odredbama (osobito u odnosu na čl. 16., 17. i 101. Ustava RH) o ograničavanju prava i sloboda te izvanrednim stanjima, uz kazuistički (case law study) prikaz sudske prakse, poglavito recentnih odluka Ustavnog suda Republike Hrvatske (dalje u tekstu: USRH) vezanih uz opću problematiku uzrokovanu epidemijom COVID-19.

\section{Ciceronov koncept dobrobiti i spasa naroda kao vrhovnog zakona}

U Zakonima, osobito u prve dvije knjige (Liber primus et secundus), Ciceron u obliku dijaloga razrađuje ključan aspekt političko-pravne obnove Rimske republike u kontekstu prirodnoga prava, konfrontirajući koncept zakona (prava) kakav trenutno 
jest (de lege lata) s time kakav bi trebao biti (de lege ferenda). Takva ontološka metodika propitkivanja fenomena prava (kao i, a maiore ad minus, zakona ${ }^{4}$ koji po Ciceronu mora biti formalan i (za)pisan; Ciceron, 1996, str. 20), ponajviše u pogledu, za Cicerona, neoborive premise o imanenciji prirodnog prava, doprinosi svrstavanju Cicerona među ključne začetnike ideje prirodnog prava (vidjeti npr. Straumann, 2015), ali i filozofije prava općenito.

U trećoj knjizi Zakona (Liber tertius) Ciceron prilično pragmatično na prirodnopravnim osnovama postavlja temelje svojevrsnog rimskog ustava, raspravljajući o pravosudnom sustavu, Senatu, magistratima, plebejskim tribunima, načinima glasovanja, ali i vlasti općenito. Ono što se također može iščitati iz Ciceronova diskursa u Zakonima, a što potvrđuju i određena tumačenja (Straumann, 2011), jest kako u trećoj knjizi, gdje govori o temeljnim pravnim postavkama Republike, pod terminom lex Ciceron ni u jednom trenutku ne govori o "popularnim" i u tom trenutku postojećim zakonima iza kojih stoji točno određena i pravno utvrđena procedura, već upravo o onim zakonima koji emaniraju iz prirodnog prava, a o kojima detaljnije piše u prvoj i drugoj knjizi Zakona. Ciceron jasno navodi (1996, str. 64): “onaj zakon, čiju sam narav izložio, nemoguće je bilo ukinuti, bilo opozvati”, na što njegov brat Kvint dodaje: "Predložit ćeš dakle zakone, koje se nikad neće opozvati?" Straumann (2011, str. 290) tvrdi kako se kontekst prve dvije knjige Zakona gdje Ciceron raspravlja o konceptu prirodnih zakona nije izgubio ni u trećoj, za koju bi se možda moglo smatrati kako isključivo ima funkciju elaboracije Ciceronovog vlastitog viđenja "pozitivnopravne" situacije tadašnje Republike. Ciceron u trećoj knjizi govori o zakonima koji emaniraju iz prirodnog prava, tvoreći tako rimski ustav koji je "qua prirodnog prava, koji je univerzalan i ne historijski kontingentan" (ibid.). Ciceronov prirodnopravni koncept predstavljen u prve dvije knjige Zakona prisutan je i u trećoj te Ciceron, upravo u vidu problematike vlasti, smatra kako ona eo ipso emanira upravo iz temelja uspostavljenih prirodnim pravom:

Ukratko, ništa nije tako usklađeno s prirodnim pravom i redom (kad to kažem, hoću da se zna da govorim o zakonu) kao vlast, bez koje nijedna kuća ni grad ni cjelokupan ljudski rod ne mogu opstati, pa ni sva priroda i sam svijet. I on naime sluša boga, a njemu se pokoravaju mora i zemlje; i ljudski je život poslušan naredbama vrhovnog zakona (Ciceron, 1996, str. 116).

${ }^{4}$ Prema Ciceronu (1996, str. 20), osnovu prava treba izvoditi upravo iz zakona, polazeći pritom od premise kako je zakon, i u etimološkom i u lingvističkom pogledu (grčki vó $\mu o \varsigma$, izvorni "udio", od vé $\mu \omega=$ dijeliti, u smislu "davanja svakomu onoga što mu pripada"; i latinski lex od lego 3. = skupljati, birati, u smislu biranja pravilnog od nepravilnog, grešnog postupanja), skovan od "najučenijih" (najmudrijih ljudi) kao "najviši razum usađen u prirodu, koji nalaže što treba činiti, a zabranjuje protivno tomu", gdje se determinira distinkcija između ispravnog i neispravnog (cf. Brown, 2009, str. 331-332). 
Vrhovni (najviši) zakon ${ }^{5}$ (suprema/summa lex) Ciceron spominje nedugo poslije navedenog citata, $i$ to $u$ vidu tvrdnje o dobrobiti i sigurnosti (spasu) naroda kao najvišem zakonu koji se imperativno nameće kao svojevrsni modus operandi izvršne vlasti: "Kraljevsku vlast neka imaju dvojica, i oni neka se prema prethođenju, suđenju, savjetovanju zovu pretorima, sucima, konzulima. U vojsci neka imaju najviše ovlasti nikome se ne pokoravajući. Dobrobit ${ }^{6}$ naroda neka im je vrhovni zakon" (ibid., str. 120). ${ }^{7}$

Takvu Ciceronovu elaboraciju potrebno je promatrati u historijskom kontekstu, utemeljenom odredbama rimskog (javnog) prava. Atribut "kraljevska" u regio imperio upotrebljava se u pogledu one vlasti koju su dvojica konzula Rimske republike, kao, izvorno, nositelji vlasti in toto, naslijedila od kraljeva Rimskog kraljevstva (od 509. g. pr. Kr.). U rimskom (javnom) pravu (izvršna) vlast, odnosno imperium odnosi se na: pravo zapovijedanja vojskom, civilnu i kaznenu jurisdikciju, sazivanje narodnih skupština i Senata na zasjedanje, izdavanje edikta te primjenu različitih kaznenih mjera (Romac, 1983, str. 138). Gerundi praeeundo, iudicando, consulendo, nadovezuju se na magistratne funkcije, ${ }^{8}$ koje su etimološki izvedene iz glagola: konzul i pretor (više magistrature, magistratus maiores) od consulo 3 . = savjetovati, vijećati, brinuti se, i praeeo, ire = ići (u)naprijed, ${ }^{9}$ sudac od iudico $1 .=$ suditi (vidjeti Ciceron, 1996, str. 120). Naime, u samim počecima Rimske republike magistratima, odnosno dvama konzulima biranim na godišnjoj razini bile su povjerene sve djelatnosti državne vlasti. Međutim, u teritorijalnom proširenju Rimske republike povećao se i opseg dužnosti državne vlasti, te je 367 . g. pr. Kr. postavljen

5 Vrhovni zakon (suprema lex; summa lex), univerzalan i vremenski nepromjenjiv, zakon prirode (lex naturae), potječe od samog boga te je samim time determiniran vrhovnim razumom (summa ratio) čime se može izvesti i aksiom izjednačavanja - "natura $=$ summa lex $=$ ratio summa" (Lučić, 2006, str. 89; tako i: Ciceron, 1995, str. 172).

${ }^{6}$ Odnosno sigurnost, spas, čak i zdravlje.

7 "Regio imperio duo sunto, iique $<a>$ praeeundo iudicando consulendo praetores iudices consules appellamino. Militiae summum ius habento, nemini parento. Ollis salus populi suprema lex esto" (Ciceron, 1996, str. 121).

${ }^{8}$ U vrijeme Republike uspostavljena je tzv. magistratura koja se odnosila na osobe (magistrate) koji obavljaju određenu javnu službu: diktatori, konzuli, pretori, cenzori (više magistrature) te kurulski edili, kvestori i vigintisexviri (više u Pina Polo, 2016; Vervaet, 2016). U Zakonima Ciceron raspravlja na koji način treba pravilno urediti magistraturu koju smatra svojevrsnim "razumom" države i prava: "Vidite dakle da je magistratova moć biti pretpostavljen i propisivati ono što je pravilno, korisno i u skladu sa zakonima. Kao što su magistratima nadređeni zakoni, tako su magistrati narodu, i opravdano je nazvati magistrata zakonom koji govori, a zakon nijemim magistratom" (Ciceron, 1996, str. 116).

9 Tako će Ciceron o ulozi i funkciji pretora: "Sudac, koji će suditi u privatnim parnicama ili naređivati suđenje, neka bude pretor. On neka je čuvar građanskog prava. Po moći mu ravnih neka bude onoliko koliko senat odredi i narod zapovijedi" (Ciceron, 1996, str. 120). 
pretor, kao još jedan magistrat, po važnosti odmah iza konzulata, biran na godišnjoj razini, kojemu su povjerene pravosudne dužnosti (o čemu piše i Tit Livije u Ab urbe condita, VI.XLII, VII.I), osobito kada konzuli nisu bili prisutni u Rimu (Pina Polo, 2016, str. 91). Nakon Drugog punskog rata (241. pr. Kr.) stvoren je i drugi pretor te je od tog vremena pretorska funkcija bila dvojaka: pravosudna u Rimu i vojna u rimskim provincijama (ibid.). Daljnjim povijesnim zbivanjima (Brennan, 2001), ratnim osvajanjima i aneksijama te stvaranjem novih provincija broj pretora uvelike se povećao. Tome je pridonijela i Sulina reforma o povećanju stalnih sudova za posebne delikte (81. pr. Kr.), kojom je pretura izgubila vojne ovlasti (Pina Polo, 2016, str. 91), a za vrijeme Cezara bilježi se brojka od šesnaest pretora (Romac, 1983, str. 265). Pretoru je pripala dužnost da u dvodijelnim pravnim postupcima nadzire prvi, formalni i najvažniji dio procesa vezan uz pravno stanje i drugi koji se odnosi na razradu činjeničnog stanja. Daljnjim odmakom pravosuđa utvrđeno je kako je upravo drugi dio postupka koji se odnosi na razradu činjenica najsporniji i da oduzima najviše vremena, te ga je, uz prethodnu odluku pretora o predmetu spora (formula), mogla obavljati i osoba bez posebne pravne naobrazbe zvana iudex (više u Stein, 2007, str. 16-17).

No Ciceronova se maksima primarno odnosi na dvojicu konzula, odnosno diktatora, kao glavnih predstavnika izvršne vlasti, odnosno monarhije iz Ciceronovog i Polibijevog koncepta mješovitog ustava, koji u vlastitom djelovanju i općenito i $\mathrm{u}$ izvanrednim situacijama trebaju djelovati pro salute populi. Ciceron s razlogom sintagmu dobrobiti naroda dovodi $\mathrm{u}$ isti rečenični i semantički kontekst s prirodnim pravom, odnosno vrhovnim zakonom (suprema lex). Poput Platona i Aristotela, ${ }^{10}$ Ciceron mutatis mutandis takvu prirodnopravnu zakonitost temelji na činjenici o

${ }^{10}$ Dobrobit naroda (zajednice) jest jedan od glavnih ciljeva države kao one zajednice koja "nastaje radi održanja života" i u koju se čovjek udružuje po svojoj prirodi jer je i sam čovjek "po

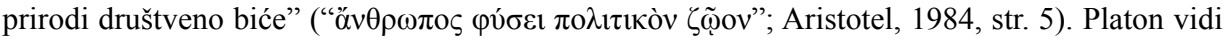
državu kao zajednicu veću od čovjeka samog koja nastaje jer "svatko od nas nije sebi dosta, nego mu mnogo treba i potrebni su mu drugi” (Platon, 2009, str. 107), posebno naglašavajući kako dobrobit zajednice (države) ima prednost nad dobrobiti individue (vidjeti Platon, 1982, str. 82 i 83). Potonje navodi i Aristotel (što je recipirano i u čl. 16. i 17. Ustava RH), koji dodatno razrađuje teleologiju države navodeći kako je cilj države osigurati "najbolji život" svakom pojedincu koji vlastite moći na slobodan način koristi u svrhu dobra zajednice: "ona (država) nastaje radi održanja života, a postoji radi sretnog života (...) Uz to svrha zbog koje je nešto nastalo predstavlja najviši cilj. A samodovoljnost je i cilj i najveće dobro (...) Jasno je, dakle, da država nastaje po prirodi i da je važnija nego pojedinac (...) A onaj koji ne može živjeti u zajednici ili kome ništa nije potrebno jer je sam sebi dovoljan, nije dio države, te je ili zvijer ili bog. U svim ljudima, dakle, postoji prirodna težnja za takvom zajednicom i onaj tko ju je prvi osnovao začetnik je najvećeg dobra" (Aristotel, 1984, str. 5). Tako se i u Dužnostima Ciceron (2006, str. 16) nadovezuje na stoičko shvaćanje prirodnog prava prema kojemu ono što je časno jest uvijek korisno jer častan čovjek teži zajedničkom dobru, odnosno služenju “u ime opće koristi” (Aßländer, 2013, str. 752). 
državi kao prirodnoj zajednici ljudskog bića, imanentnoj pojedincu, kojoj je dobrobit naroda $u$ vidu zajedništva ne kao pukog instrumentarija za postizanje vlastite koristi (utilitas), već kao bivstvovanja s drugima ipso facto (utilitas communione), jedan od glavnih svrha ( $\tau \dot{\lambda} \lambda o \varsigma$ ) postojanja uopće. Ciceronova konstrukcija o supremaciji dobrobiti naroda neodvojiva je od njegova viđenja rei publicae kao "stvari naroda", odnosno udruženja "naroda kao ne bilo kakve skupine ljudi, nego skupine mnoštva udružene prihvaćanjem prava i zajedničkom korišću” (Ciceron, 1995, str. 48). Država kao javna stvar / res publica vlastitu bit više ne ispunjava u onom trenutku kada se zajednica ne ravna načelima utemeljenim prirodnim pravom (pravednosti) i zajedničkom koristi čije zanemarivanje se "protivi Prirodi, jer je u odnosu na društvenu zajednicu nepravedno" (Ciceron, 2006, str. 151). Otuda i etimološko ishodište riječi res publica, koje je u neraskidivoj vezi s res populi, što se prevodi kao "stvar naroda", odnosno "stvar u vlasništvu naroda" (cf. Smith, 2018, str. 13-14). Shodno navedenome, takvo viđenje rei publicae, koncepta izvedenog iz naroda kao zajednice zajedničkog interesa, najbolje se reflektira upravo u činjenici da se na određenim mjestima (npr. Harries, 2016, str. 135), pa i u našoj literaturi (Smerdel i Sokol, 2009, str. 125; Petrak, 2010, str. 123) koristi izvedena "inačica" maksime o supremaciji dobrobiti naroda u vidu supremacije dobrobiti države (republike) - salus rei publicae suprema lex esto, kao i salus patriae suprema lex (Stojčević i Romac, 1971, str. 449). Takav je pristup o prirodnom pravu države (republike) jedno od izvorišta teorije (ideje) o državnom centrizmu, odnosno prirodnom pravu države na samo-postojanje $\mathrm{u}$ izvanrednim (hitnim) situacijama, u konfrontaciji s pozitivističkim nastojanjima o ustavnoj regulaciji izvanrednih stanja (tzv. teorije ustavnog centrizma).

Ciceronovu je pak maksimu mnogo lakše pojmiti ako se sagleda kompletan povijesni kontekst tadašnjih turbulentnih zbivanja u Republici u kojima su istaknuti viši magistrati, naročito u tzv. kriznim situacijama (kada po rimskom pravu može nastupiti i diktatura), kršili dane ovlasti radi zadovoljenja vlastite koristi (npr. Sula, Cezar, Marko Antonije te kasnije i Oktavijan), ne mareći za zajedničku, što je naposljetku i dovelo do onoga od čega su sam Ciceron i ostali republikanci najviše strepili - pada Republike i stvaranja principata (31. g. pr. Kr.). U Ciceronovo se vrijeme, u doba Rimske republike, za izvanrednih prilika vlast koncentrirala u egzekutivi, ili od samih konzula ili od jedne osobe - diktatora (lat. dictator, od dicto 1. = kazivati, nalagati), kao one koja predstavlja preteču suvremenijih koncepcija uloge izvršne vlasti u izvanrednim stanjima. U Rimskoj republici diktatoru je cjelokupnu državnu vlast povjeravao konzul, na prijedlog Senata, na vrijeme od, u pravilu, najduže šest mjeseci, iako su bile zabilježene situacije gdje tomu nije bilo tako (npr. 44. g. pr. Kr. Cezarovo imenovanje doživotnim diktatorom od Senata; vidjeti Beard, 2018, str. 263). Bitno je istaknuti kako je diktator imao široku zakonodavnu, sudsku 
i upravnu vlast te kako su mu bili podređeni i konzuli i ostali magistrati, što je općenito doprinijelo tranziciji republikanskog u monarhijski sustav ( $c f$. Romac, 1983, str. 92). Klasični teoretičar izvanrednih stanja Carl J. Friedrich (1968, str. 559), nešto drugačije od Cicerona, dodatno razrađuje koncept širokih ovlasti rimskog diktatora, tvrdeći kako vlast diktatora proistječe iz ustava, ali i kako njezin cilj mora biti "obrana postojećeg ustavnog poretka", a ne njegovo uništenje (tako i Gardašević, 2014, str. 162), odnosno očuvanje države i ustavnog poretka te ljudskih prava i sloboda (salus populi et rei publicae). Navedeno ne treba čuditi, jer je i sam Friedrich (2012), kao suvremenik, bio poučen negativnim iskustvima zlouporaba ovlasti u Weimarskoj Republici dolaskom nacista na vlast. Friedrich (1968) prilično jasno kaže kako "izvanredne ovlasti moraju biti vrlo široke u opsegu", ali kako "uvjeti za njihovu primjenu moraju biti striktno definirani” (u Gardašević, 2014, str. 323). Clinton Rossiter (2011) također razrađuje navedeni koncept, zalažući se za oblik ustavne diktature u kojem se diktatorske ovlasti izvršavaju u slučaju nužde, ali, za razliku od Cicerona, u granicama danim ustavom i uz tri reducirana kriterija legitimiteta modela: kriterij uvođenja izvanrednih stanja, kriterij njihovog produženja i kriterij okončanja (Gardašević, 2014, str. 321).

Ciceron nadalje smatra kako (na tom tragu i Friedrich i Rossiter; Gardašević, 2014, str. 162 i 321) Senat ima ovlast odlučiti hoće li se vlast dodijeliti diktatoru (tako i Friedrich, 1968, u: Gardašević, 2014, str. 162), koji pak treba imati ista prava kao i dva konzula, ali pod uvjetom da je diktator jedini predstavnik egzekutive u tom razdoblju:

Ako dođe do težeg rata ili nesloge građana, jedan, ako Senat odluči, neka drži isto pravo kao dva konzula, samo ne više od šest mjeseci; on, proglašen uz povoljnu pticu, neka je magister naroda. Neka ima zapovjednika konjice s istim pravima kao oni koji budu suci. Ostali magistrati neka ne budu (Ciceron, 1996, str. 120).

Ciceron imperativno pokušava naglasiti kako viši magistrati (točnije, primarno konzuli, ali i diktator), kao predstavnici rei publicae ${ }^{11}$ koji obnašaju javnu funkciju, vlastito javno djelovanje trebaju obnašati isključivo u korist naroda (pro salute populi), uzimajući njegovu dobrobit, sigurnost i zdravlje kao svojevrsni modus operandi. Ciceron navedeno iskazuje i u Prvom govoru protiv Katiline, gdje kao konzul i homo novus (skorojević, osoba čiji preci prethodno nisu obavljali državničke duž-

11 Akronim Rimske republike bio je upravo SPQR (Senatus Populusque Romanus - Rimski Senat i narod), koji se odnosio na klasno uspostavljeno stanovništvo Rima - Senat kao glavno upravno-ustavno, i aristokratsko, tijelo (prvobitno sastavljeno od patricija) i obično građanstvo (populus). Osim navedenog akronima koji je zabilježen u Ciceronovim govorima, prema određenim navođenjima (Dyck, 2004, str. 459), Ciceron kraću izvedenicu maksime salus populi suprema lex, salus populi Romani, koristi čak 18 puta u svojim govorima (15 puta u onima za vrijeme i nakon Katilinine urote) te dva puta u svojim pismima. 
nosti) zagovara koncept služenju narodu i Republici. Straumann ističe (cf. 2011, str. 288) kako tvrdnju o supremaciji dobrobiti naroda i Republike, koju Ciceron stavlja $\mathrm{u}$ isti kontekst $\mathrm{s}$ višim magistratima, treba promatrati u vezi s činjenicom kako navedeni magistrati u obavljanju svojih dužnosti uistinu jesu pravno (lex) ograničeni, ali kako se izraz lex u Ciceronovim Zakonima odnosi na refleksiju prirodnog prava, što bi u konkretnom slučaju značilo kako viši magistrati nemaju ovlasti da prijeđu "fundamentalne norme" koje se, u svojoj biti, odnose upravo na dobrobit i sigurnost naroda i Republike: "Kao što su magistratima nadređeni zakoni, tako su magistrati narodu, i opravdano je nazvati magistrata zakonom koji govori, a zakon nijemim magistratom" (Ciceron, 1996, str. 116).

Takvu vrstu ograničenja koju spominje Straumann ne treba miješati s ograničenjem koje je povezano s normama pozitivnog prava. Jer Ciceron očigledno smatra kako konzuli imaju pravo prijeći vlastite ovlasti (nemini parento ${ }^{12}$ ) u slučajevima nužde i hitnosti, bez potrebe da takve ovlasti i radnje dodatno potvrđuje i ovlašćuje Senat posebnim mišljenjem (tako i Walker Keyes, 1921, str. 317-319), u rimskom pravu poznatom kao senatus consultum ultimum, na temelju kojeg konzulima pripada neograničena vlast za vrijeme izvanrednih stanja. Nakon prestanka mandata, kada može biti subjektom pravnih progona zbog određenih nelegalnih radnji, konzul bi pred cenzorima morao opravdati vlastite, ipak u tom trenutku ne-legalne, radnje koje je poduzeo i dokazati kako je salus populi uistinu bilo u opasnosti te kako je upotreba takvih mjera bila potrebna za njegovo očuvanje. Walker Keyes (ibid., str. 318) navodi kako je Ciceron imao točno određeni razlog da konzulima daje takve ovlasti, koji se reflektira u činjenici "da je konzulat najslabija točka u identificiranju teoretski uspostavljenog 'uravnoteženog ustava' Grka s aktualnim ustavom Rima”. Naime, izvršnu vlast u vidu konzulata bilo je potrebno učvrstiti jer je odnos moći iz Ciceronovog i Polibijevog koncepta mješovitog ustava bio narušen u korist demokratskog i aristokratskog elementa (Senat) istog, osobito uspostavljanjem (o)vlasti Senata na pravno utvrđenoj bazi kao ne više samo savjetodavnog tijela. Navedenu bi ovlast konzuli imali pravo koristiti vlastitom diskrecijskom ocjenom, procjenjujući kada bi to bilo potrebno, ali uz naznaku kako su isključivo oni odgovorni za korištenje takvih ovlasti. ${ }^{13}$ Itekako je zamjetno da Ciceron navedenim pokušava osnažiti izvršnu vlast, naročito u izvanrednim situacijama opasnosti po Republiku, bez obzira hoće li u tom trenutku kompletna delegacija vlasti pripasti konzulima

${ }^{12}$ Iako je navedeno ("nikome ne pokoravajući se") Ciceron postavio u kontekstu vojske, koncentrirajući sve vojne ovlasti u egzekutivu, što je dio i suvremenih pravnih poredaka, zapravo pokušava općenito naglasiti važnost davanja većih ovlasti egzekutivi.

13 Tako i Gross i Ní Aoláin (2006, str. 111) zastupaju upravo stajalište kako javni dužnosnici mogu djelovati izvan prava pod uvjetom da otvoreno i javno priznaju prirodu svojih akcija (Gardašević, 2014, str. 155). 
ili pak diktatorima, ali uz temeljno načelo kako im sigurnost naroda i države mora biti primarno pri djelovanju. Jer upravo tim načelom Ciceron pokušava uspostaviti određenu mjeru kako izvršna vlast ne bi prekoračila vlastita ovlaštenja, u vidu toga kako sve radnje koje se poduzimaju, bilo u redovnim, bilo u izvanrednim situacijama, moraju biti vođene isključivo mišlju o dobrobiti naroda i republike. Mogli bi se reći kako Ciceron senatus cosultum ultimum zamjenjuje uvjetom pro salute popu$l i$, gdje je egzekutiva isključivo odgovorna za mjere koje poduzima. Ograničenje, kao svojevrsni prirodnopravni legitimni cilj, koje se određuje konzulovu vladanju u izvanrednim okolnostima jest da ono mora biti isključivo u korist dobrobiti naroda, što za Cicerona, kao što je pokazano, predstavlja prilično ozbiljan uvjet, možebitno ozbiljniji i od samog odobrenja Senata.

\section{Recepcija salus populi suprema lex (esto) i suvremene (ustavne) odredbe o ograničavanju prava i sloboda te izvanrednim stanjima}

Ciceronovu konstrukciju o dobrobiti i spasu naroda, kao i mogućnost djelovanja izvan prava u izvanrednim okolnostima, razrađivali su i ostali klasični teoretičari izvanrednih stanja. Hobbes u Levijatanu sintagmu salus populi razmatra u vidu dobrobiti naroda kao osnovnoj namjeni države:

Jer umijećem je stvoren onaj veliki LEVIJATAN, nazvan ZAJEDNICOM ili DRŽAVOM (na latinskom CIVITAS), koja nije ništa drugo do umjetni čovjek, premda je većeg stasa i jačine od onog prirodnog, čijoj zaštiti i obrani je namijenjena (...) njezina namjena je salus populi (dobrobit naroda) (Hobbes, 2013, str. 11).

John Locke u Dvije rasprave o vladi (Locke, 2013, str. 287) eksplicitno spominje Ciceronovu konstrukciju tvrdeći kako je "Salus populi suprema lex, svakako opravdano i temeljno pravilo, i onaj tko ga iskreno usvaja, ne može opasno pogriješiti." Lockeova percepcija Ciceronove maksime bazira se na činjenici kako "krajnji temelj legitimacije ne leži u volji naroda (tzv. načelo voluntas populi suprema lex), već upravo u njegovoj dobrobiti" (Moots i Forster, 2010, str. 40). Locke na Ciceronovom tragu razrađuje koncept tzv. prerogativa, odnosno razborite vlasti činjenja općeg dobra bez pravila i zakonskog propisa kako bi se "sačuvali svi članovi društva" u vidu osnovnog zakonu vlasti i prirode iz razloga što katkada "strogo i kruto držanje zakona može nanijeti štetu" (Locke, 2013, str. 289). Upravo je potonje, što je još jedan od argumenata u prilog Ciceronovom zagovaranju izlaska iz sfere prava, zasnovano na drugoj Ciceronovoj maksimi, summum ius summa iniuria, sadržanog u Dužnostima (Ciceron, 2006, str. 125), prema kojemu najdosljednije držanje prava može naposljetku dovesti do najveće nepravde. Prema Carlu Schmittu, "tendencije suvremenog pravnodržavnog razvoja smjeraju u tom smislu na uklanjanje suverena", ali "pretpostavka i sadržaj nadležnosti” u ekstremnom slučaju nužde "nužno su neograničeni” (Schmitt, 2019, str. 14). Gross i Ní Aoláin, kao suvremeni 
pobornici izvan-pravnog djelovanja, njegov temelj vide u kritici mehanizma sudbenog nadzora (pogledati primjerice infra Rješenje USRH od 24. 6. 1992.) i mehanizma diobe vlasti (Gardašević, 2014, str. 153).

Dvije glavne teorije imaju primjenu u tzv. situacijama izvanrednog stanja - teorija državnog centrizma i teorija ustavnog centrizma. Teorija državnog centrizma počiva na ideji kako država ima nad-zakonsko pravo, temeljeno na prirodnom pravu, na vlastitu samoočuvanost i postojanje, a koja ne može biti ograničena pozitivnim pravom ( $c f$. Stern, 1980, str. 1337). Pravna norma primjenjuje se samo u regularnim i "normalnim" situacijama te se ne može primijeniti u izvanrednoj situaciji koja krije opasnost za pravo na postojanje države (tako Von Jhering, 1923, str. 330; Scheuner, 1950, str. 318). Naime, prema nekim autorima, korijeni te teorije temelje se upravo na razrađivanoj Ciceronovoj maksimi o prirodnom pravu države, odnosno vrhovnosti spasa države (salus rei publicae suprema lex; vidjeti Jakab, 2005, str. 467), kao i na Hegelovoj percepciji države kao nadmoćne institucije (tako Koja, 1979, str. 12).

Teorija ustavnog centrizma bazira se na pozitivističkoj ideji kako sve ovlasti za vrijeme izvanrednih stanja proistječu iz ustava te moraju njime biti eksplicitno regulirane, čime se smanjuje opasnost zlouporabe ovlasti. Sve ono što počiva na bilo kakvoj ideji supra-konstitucionalnog stanja nužde, prema Arndtu (1962), jest "ustavna izdaja", dok Kelsen (1925, str. 157) smatra kako je ideja da država mora živjeti eo ipso "naivna" i podložna različitim željenim tumačenjima onih koji smatraju da ona mora živjeti (tako i Jakab, 2005, str. 472). Teorija državnog centrizma bazira se na želji za efikasnošću, teorija ustavnog centrizma na strahu od zlouporabe moći, dok mješovite teorije teže "kompromisu između same efektivnosti i straha od zlouporabe", a sama primjena i kategorizacija trenutne pravne zbilje u odnosu na navedene teorije ovisit će o konkretnoj pravnoj kulturi i pravničkim shvaćanjima (vidjeti ibid., str. 477). ${ }^{14}$

Ustavom Republike Hrvatske (NN, Pročišćeni tekst, br. 56/90, 135/97, 8/98, 113/00, 124/00, 28/01, 41/01, 55/01, 76/10, 85/10, 5/14; dalje u tekstu Ustav) zakonsko ograničavanje prava i sloboda predviđeno je čl. 16., 36., 37., 38. (također i 39., kao norma ustavnog ranga), 50. i 61., dok je ograničenje prava i sloboda u situacijama nužde i izvanrednih mjera predviđeno čl. 17. i 101. U pogledu čl. 16. i 17. Ustava, situacija pojave epidemije COVID-19 iznjedrila je veliku dvojbu o tome

14 Tako se konture ustavnog centrizma ocrtavaju u čl. 54. Mađarskog ustava (Magyarország Alaptörvénye), prema kojem u vrijeme posebnih pravnih poredaka "primjena Temeljnog zakona (Ustava) ne smije biti suspendirana, a rad Ustavnog suda ne može biti ograničen”, što je dio shvaćanja unutar mađarske pravne kulture (Jakab, 2005, str. 476). S druge strane, određene je ustave, poput njemačkog (Grundgesetz für die Bundesrepublik Deutschland), prilično teško kategorizirati zbog različitog shvaćanja prirode njemačkih ustavnih odredbi o izvanrednim stanjima (ibid., str. 475). 
treba li se epidemija promatrati u okviru čl. 16. Ustava, kako je vladajući trenutno i promatraju, ili pak kao prirodna nepogoda ${ }^{15}$ i samim time u okviru čl. 17. Ustava?

Čl. 16. ${ }^{16}$ Ustava nalaže da se ljudska prava i slobode mogu ograničiti samo zakonom radi zaštite opstojnosti države (republike), odnosno naroda ("drugih ljudi") u vidu legitimnog cilja zaštite: "slobode i prava drugih ljudi, pravnog poretka, javnog morala i zdravlja". Navedeni članak promatra se u vidu toga kako se ograničavanje prava i sloboda može provoditi radi zaštite navedenih elemenata uz primjenu načela razmjernosti prema kojemu "svako ograničenje slobode ili prava mora biti razmjerno naravi potrebe za ograničenjem u svakom pojedinom slučaju" (st. 2.). ${ }^{17}$

Međutim, iako se Ciceronova maksima odnosi na izvanredna stanja, tako određeni objekti zaštite koji su predviđeni čl. 16. povod su za određene zanimljive polemike koje se mogu promatrati u kontekstu Ciceronove misli općenito. Prije svega, članak 16. navodi zaštitu "pravnog poretka", koji se ne mora nužno shvatiti na pozitivistički način. Čak ako pravni poredak shvatimo isključivo kao skup pravnih normi (Guastini, 2016, str. 35) u vidu ustavne pravne države u kojoj vladaju načela ustavnosti i zakonitosti, već idući objekt zaštite nudi nova pitanja. Prilično je zanimljivo kako pozitivistički determinirano zakonsko ograničavanje prava iz čl. 16. eksplicitno podrazumijeva i zaštitu javnog morala. Pravo je pitanje koliko je to dosljedno s obzirom na pozitivističku prirodu takve odredbe i je li takvo nešto uistinu moguće učiniti? Je li moguće pravo i moral uopće svesti u istu kategoriju te na bilo koji način zaštititi ipak nedovoljno određeni pojam javnog morala putem pravnog instrumentarija (vidjeti primjerice Baccarini, 2006)? Jer ako uistinu govorimo o

15 Vidjeti elaboraciju sudaca Selanec, Kušan i Abramović u Izdvojenom mišljenju u odnosu na rješenje USRH u predmetima broj: U-I-1372/2020, U-I-1999/2020, U-I-2075/2020, U-I2233/2020, U-I-2161/2020 i U-I-2234/2020 od 14. rujna 2020. Također vidjeti Prijedlog za pokretanjem postupka za ocjenu suglasnosti s Ustavom, s člancima 10., 13., 14. i 18. ZIDZZP-a/20 (predmet broj: U-I-2075/2020) Peđe Grbina koji “(...) predlaže pokretanje postupka za ukidanje pobijanih odredaba jer se postavljaju pitanja je li epidemija bolesti COVID-19 'velika prirodna nepogoda' u smislu članka 17 . Ustava (...)”.

${ }^{16}$ U okviru čl. 16. Ustava RH treba ukazati na dva zakona koji su, poradi ograničavanja ljudskih prava i sloboda zbog pandemije COVID-19, ove godine doživjeli izvjesne izmjene i dopune (Zakon o izmjenama i dopunama Zakona o sustavu civilne zaštite, NN, br. 31/20, i Zakon o izmjenama i dopunama Zakona o zaštiti pučanstva od zaraznih bolesti, NN, br. 47/20 i 134/20). Prvi je Zakon o sustavu civilne zaštite (NN, br. 82/15, 118/18, 31/20), a drugi Zakon o zaštiti pučanstva od zaraznih bolesti (NN, br. 79/07, 113/08, 43/09, 130/17, 114/18, 47/20, 134/20), prema kojima (čl. 22a ZSCZ-a i čl. 47. ZZPZB-a) Stožer civilne zaštite Republike Hrvatske (dalje u tekstu: Stožer) pod neposrednim nadzorom Vlade Republike Hrvatske može donositi obvezujuće odluke.

17 Pogledati Izdvojeno podupiruće mišljenje (u odnosu na Odluku USRH u predmetu broj: U-II-2379/2020 od 14. rujna 2020.) ustavnih sudaca Selanec, Kušan i Abramović o egzaktnim parametrima koje državna vlast mora primijeniti u bilo kojem ograničavanju temeljnih prava i sloboda. 
pravu kao "negaciji negacije morala" (Lauc, 2016, str. 36), ne dolazimo li ovdje do istih onih prirodnopravnih postavki kojima je bio uvjetovan i sam Ciceron? Jer već samo pitanje javnog morala ostavlja velik prostor diskrecijskoj ocjeni vlasti pri čemu se prilično fluidno izlazi iz sfere prava. Ako pak pravni poredak i javni moral stavljamo u isti kontekst dobivajući upravo tvorevinu supremae legis, tada bi to svakako moglo podrazumijevati određenu izvan-pravnu djelatnost koja obuhvaća kršenje pozitivnog prava radi zaštite navedenih kategorija, pravnog poretka i javnog morala zasebno, ali moguće i kumulativno. Schmitt tako navodi kako je i sam “pravni poredak zasnovan na odluci, a ne na normi” (Schmitt, 2019, str. 17). Dicey tvrdi kako - doduše, u okviru pojave izvanrednih stanja - "za dobro same legalnosti (engl. legality) pravna pravila moraju biti prekršena” (Dicey, 1959, str. 412). Upitno je, dakle, koliko je ustavna odredba orijentirana prema zakonskom ograničavanju prava i sloboda uz primjenu načela razmjernosti usklađena s tako razrađenim postavkama zaštite pravnog poretka i javnog morala kumulativno i zasebno.

Jedno od itekako aktualnih pitanja u pogledu pandemije COVID-19 povezano je sa zakonskim ograničavanjem prava radi zaštite javnog "zdravlja". Mnogoznačan pojam zdravlja ostavlja velik prostor različitim interpretacijama. Itekako je zamjetna različitost shvaćanja konteksta riječi salus iz Ciceronove tvrdnje. Iako se u kontekstu s riječima populus i rei publica riječ salus (-utis, $f$.) prevodi kao "dobro(bit)" "spas" i "sigurnost", značenje te riječi vezano je i uz prijevod "zdravlje". Svi navedeni prijevodi te riječi u biti imaju značenje koje se odnosi na kompletnu psihofizičku cjelovitost ljudskog bića pojedinačno i kao dijela zajednice. Tako se navedena Ciceronova tvrdnja, osobito u biomedicinskim znanstvenim krugovima (npr. Lohff, 2001, str. 545; Helfand, Lazarus i Theerman, 2001, str. 689), na ne toliko precizan način koristi upravo u okviru problematike zdravlja, odnosno zdravstvene zaštite (“zdravlje naroda neka bude najviši zakon"; Lohff, 2001, str. 545), što je determinirano djelovanjem zdravstvenog sektora. Međutim, pri takvoj determinaciji riječi salus treba biti prilično oprezan jer zamjetno je kako Ciceron, s obzirom na sve elaborirane činjenice, cjelokupni kontekst salutis populi nije formulirao s obzirom na današnje poimanje zdravlja, naročito ne u okvirima djelatnosti zdravstva. Pojam zdravlja, u okviru te maksime, treba promatrati s obzirom na primarna značenja riječi salus u kontekstu naroda i republike, "spasa", "sigurnosti" i "dobrobiti". Jer nadasve je nesumnjivo kako je pojam "zdravlja" neizostavan i neraskidiv element ljudske dobrobiti, sigurnosti te naposljetku i spasa, što se i ogleda u kompletnosti i inkluzivnosti same riječi salus. Samim time i hrvatski ustav upravo u čl. 16. spominje upravo "zaštitu (javnog) zdravlja". No, prilično mnogoznačan ${ }^{18}$

18 Tako i hrvatski ustav osim zaštite zdravlja iz čl. 16. eksplicitno spominje i pojam zaštite "prirode i ljudskog okoliša" u čl. 50., što emanira iz čl. 70. Ustava i prava na zdrav život koji u sebi uključuje mnogobojne okolišne determinante koje su ključne za prezervaciju zdravlja. Jer pojam zdravlja 
pojam zdravlja, pa i u okviru čl. 16. Ustava, nikako se ne smije shvatiti u smislu izvedenom isključivo iz (bio)medicinsko-zdravstvene sfere, točnije zdravstvene zaštite koja mu daje na određenoj vrsti ograničenosti pa i pogrešnosti u vidu Ciceronove tvrdnje. U pravnom se kontekstu, točnije kao predmet pravne zaštite, zdravlje danas percipira u okviru prava na zdravlje, u međunarodnim okvirima reguliranim Ustavom Svjetske zdravstvene organizacije iz 1946. (Preambula), čl. 25. Opće deklaracije o ljudskim pravima (NN, MU, br. 12/09) te čl. 12. Međunarodnog pakta o ekonomskim, socijalnim i kulturnim pravima (NN, MU, br. 12/93). Inkluzivnost riječi salus najbolje se reflektira u činjenici kako je upravo pravo na zdravlje inkluzivno pravo, što znači da u sebi sadrži širok spektar ostalih ljudskih prava; to je i eksplicitno navedeno 2000. godine u tzv. General Comment No. 14 (stavak 11.) od UN-ove Komisije za ekonomska, socijalna i kulturna prava (UN. CESCR, 2000). Takvo, ali i mnogo šire koncipirano poimanje pojma zdravlja s cjelokupnim humanim (fizičko, mentalno i socijalno) te naturalnim aspektom (okoliš i priroda) presudno je za status dobrobiti, sigurnosti i spasa pojedinca, a samim time i cjelokupne zajednice, čemu svjedoči činjenica o rimskom štovanju božice Salus ${ }^{19}$ kao, primarno, božice zdravlja, ali i dobrobiti naroda i republike (Salus Publica), a kasnije i samog cara (Salus Augustila; Hornblower i Spawforth, 2012, str. 1312).

Tako je primjerice u Odluci U-I-1372/2020 i dr. od 14. rujna 2020. USRH-a vidljivo kako, s obzirom na mjere nošenja maski i samoizolacije, USRH percepciju "zdravlja" temelji upravo na osnovnim elementima prava na zdravlje, točnije njegovu bitnom elementu o pravu na zdrav život iz čl. 70. Ustava. Ustavni sud nošenje maski i samoizolaciju eksplicitno stavlja u kontekst navedene odredbe iz čl. 70. Ustava RH: “(...) Svatko je dužan, u sklopu svojih ovlasti i djelatnosti, osobitu

eo ipso predstavlja prilično inkluzivan pojam oko čije su se definicije i determinacije vodile, i još uvijek se vode, mnogobrojne debate. Današnje poimanje zdravlja u određenim znanstvenim krugovima determinirano je činjenicom kako je zdravlje potrebno shvatiti na holistički način (Bautista-Valarezo et al., 2020), pri čemu su ključni mnogobrojni faktori koji utječu na čovjekov fizički, mentalni i socijalni status (Bircher, 2005), a koji dobrim dijelom izviru iz cjelokupnog čovjekovog okoliša (antropocentrička komponenta), ali i prirode (biocentrička komponenta): zdrava hrana, pitka voda, čisti zrak, funkcionalno domaćinstvo, funkcionalna zdravstvena zaštita i njega etc.

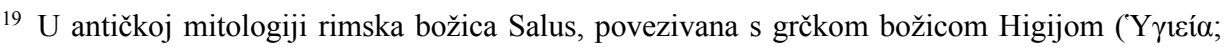
od 2. st. pr. Kr.), bila je božica zdravlja i dobrobiti kojoj je bio posvećen hram (302. g. pr. Kr.) na rimskom brdu Kvirinalu. Poseban vjerski obred augurium salutis, u razdoblju Rimske republike, bio je posvećen upravo saluti populi, odnosno dobrobiti naroda (Hornblower i Spawforth, 2012, str. 205), o čemu piše i sam Ciceron u svojem djelu De Divinatione. Znakovito je kako se, naročito s obzirom na krizne situacije i navedene prijevode "spas" i "sigurnost", obred mogao odvijati samo u danu slobodnom od ratova. Obred je nastavljen i za vrijeme principata i cara Augusta te je bio posvećen dvjema "inačicama" božice Salus: javnom zdravlju/dobrobiti (Salus Publica) ili zdravlju samog cara (Salus Augusti/Augusta, često prikazivanoj i na rimskom novcu gdje je s jedne strane bila glava cara, a s druge strane sama božica na tronu sa žezlom hraneći zmiju; više u: Hornblower i Spawforth, 2012, str. 1312). 
skrb posvećivati zaštiti zdravlja ljudi (...)", a kršenje tog prava predstavlja kazneno djelo iz čl. 180. Kaznenog zakona (NN, br. 125/11, 144/12, 56/15, 61/15, 101/17, 118/18, 126/19).

Jedno od kontroverznijih pitanja u okviru zaštite javnog zdravlja svakako je i pitanje (obveznog) cijepljenja, koje je posebno došlo do izražaja u vremenu pandemije COVID-19. Upravo je oko tog pitanja vidljivo odbacivanje Ciceronovog koncepta supremae legis uz očitu primjenu načela razmjernosti. U pravnom je aspektu potrebno naglasiti kako se, uz raspravu o zaštiti načela autonomije (samoodređenja) kao jednog od temeljnih načela biomedicinskog prava i etike (Beauchamp i Childress, 2013, str. 101; Herring, 2016, str. 8), ljudsko biće ne može natjerati ni na kakav oblik cijepljenja prisilnim i fizičkim putem, jer navedeno predstavlja kršenje jedne od temeljnih ljudskih sloboda o zabrani torture (i prisilnih znanstvenih istraživanja, čl. 23. Ustava RH). Međutim, dobro je pitanje može li ga se na to "natjerati" na druge načine te kako se atribut "obvezno" reflektira u kompletnoj COVID-19 situaciji? Iako to ne može napraviti prisilno, država može sankcionirati akt necijepljenja ako on predstavlja opasnost javnom zdravlju ljudi. Navedeno je potvrdila recentna i ujedno prva presuda Europskog suda za ljudska prava o obveznom cijepljenju, u kojoj je upravo s obzirom na načelo razmjernosti, kao jednim od elemenata, utvrđeno da država može sankcionirati akt necijepljenja ukoliko je akt cijepljenja "proglašen efektivnim i sigurnim od znanstvene zajednice" (ESLJP, Vavřička i drugi...). U tom je pogledu Sud potvrdio kako je sigurnost javnog zdravlja prevagnula nad zaštitom prava na privatni i obiteljski život iz čl. 8. Europske konvencije za zaštitu ljudskih prava i temeljnih sloboda. Samim time, u kontekstu epidemije COVID-19, ustavnih odredbi te Zakona o zaštiti pučanstva od zaraznih bolesti, neupitno je kako država može nametnuti određene sankcije, odnosno ograničenja onim osobama koje nisu cijepljene, ali samo u onim granicama koje se tiču zaštite javnog zdravlja. Bitno je pak istaknuti kako je i u nas još 2014. USRH (Odluka U-IIIB-3173/2012 od 18. ožujka 2014.), u vezi s čl. 35. Ustava (o pravu na zaštitu osobnog i obiteljskog života, dostojanstva, časti i ugleda), zauzeo stajalište kako se pri utvrđivanju postoji li pozitivna obveza upletanja države ("inherentna djelotvornom poštovanju prava na osobni život”) "polazi od razmjernosti koju treba uspostaviti između općih interesa zajednice i interesa pojedinca, pri čemu u oba konteksta država uživa određenu slobodu prosudbe". Zakonsko ograničavanje poduzetničkih sloboda i vlasničkih prava predviđeno je čl. 50., st. 2. Ustava radi zaštite tri standarda: 1) "interesa i sigurnosti RH”, 2) “prirode i ljudskog okoliša” te također 3) “zdravlja ljudi”. U tom je pogledu potrebno istaknuti kako je sam USRH određene odluke Stožera proglasio neustavnima, upravo s obzirom na povredu načela razmjernosti. ${ }^{20}$

${ }^{20}$ Odluka Ustavnog suda Republike Hrvatske broj: U-II-2379/2020 od 14. rujna 2020. i tri izdvojena mišljenja sudaca kojom se mjera Stožera o zabrani rada nedjeljom proglašava neustav- 
Čl. 17. Ustava nalaže ograničavanje prava i sloboda koje se provodi uslijed izvanrednih stanja: 1) "u doba ratnog stanja", 2) "neposredne ugroženosti neovisnosti i jedinstvenosti države" te 3 ) "velikih prirodnih nepogoda" (st. 1.). O navedenome "odlučuje Hrvatski sabor dvotrećinskom većinom svih zastupnika, a ako se Hrvatski sabor ne može sastati, na prijedlog Vlade i uz supotpis predsjednika Vlade, Predsjednik Republike" (st. 1.). U praksi USRH (U-I-1372/2020 i dr. od 14. rujna 2020.) navedeno je kako "Hrvatski sabor može u ostvarivanju svoje zakonodavne ovlasti kada ograničava pojedina ljudska prava i slobode postupati na temelju dviju ustavnih osnova predviđenih člancima 16. i 17. Ustava", ostavljajući u nadležnost Hrvatskom saboru koji će se članak primijeniti u konkretnom činjeničnom stanju. Aktualizaciju čl. 17. u našim je prilikama ozbiljila pandemija COVID-19 u vidu pitanja je li navedeni članak relevantan za primjenu u konkretnoj situaciji. Ako je zdravlje naroda (javno zdravlje) u tolikoj opasnosti da zahtijeva stroge mjere poput ograničenja kretanja te zatvaranja brojnih javnih objekata, opravdano je govoriti o onim razmjerima ugroze javnog zdravlja koji bi se uistinu mogli okarakterizirati kao prirodna nepogoda (tako i Gardašević, 2020, str. 3). Teškoće koje se javljaju reflektiraju nekoherentnost čl. 17. i čl. 101. Ustava te veliku neodređenost pojma "velika prirodna nepogoda", na što su, u vidu neodređenosti i dvosmislenosti pojma "izvanredna (stanja)" koje je tada ostavljeno političkoj odluci, upozoravali glavni protagonisti teorija izvan-pravnih djelovanja Gross i Ní Aoláin (Gardašević, 2021, str. 33). Gardašević, između ostalog, u tom pogledu upozorava na nekoherentnost pojmova "velika prirodna nepogoda" i prirodna nepogoda (Zakon o ublažavanju i uklanjanju posljedica velikih prirodnih nepogoda, NN, br. 16/19), uz potrebu da USRH da svoje tumačenje COVID-19 kao "velike prirodne nepogode" (Gardašević, 2021, str. 39). Nekoherentnost između čl. 17. i 101. na koju upozorava Gardašević ogleda se u činjenici kako "velike prirodne nepogode" (jedna od četiri ustavne kategorije uz ratno stanje, stanje neposredne ugroženosti i jedinstvenosti i (opstojnosti) države te nemogućnost tijela državne vlasti da redovito obavljaju svoje ustavne dužnosti) spominje samo čl. 17 (ibid., str. 33). Nadalje, dok čl. 17. predviđa nemogućnost Hrvatskog sabora da se sastane, standard "nemogućnosti iz čl. 101. mnogo je širi i odnosi se na nedefiniran krug državnih tijela" (ibid.). ${ }^{21}$

Nadalje, bitno je navesti kako ograničenje prava i sloboda iz st. 1. čl. 17. "mora biti primjereno naravi pogibelji, a za posljedicu ne može imati nejednakost osoba s

nom. Glavni razlog jest upravo povreda načela razmjernosti jer ne čini se "nužnom" odluka da trgovine ne rade u razdoblju poboljšane epidemiološke situacije i ublažavanja sveopćih epidemioloških mjera, naročito jer su trgovine u vrijeme uvođenja strogih mjera tijekom ožujka 2020. godine radile svakodnevno.

${ }^{21}$ O daljnjim problemima definiranja i određenja navedenih ustavnih kategorija te koherentnosti između čl. 17. i čl. 101., kao i općenito problematici COVID- 19 kao "velike prirodne nepogode" u konetkstu Ustava RH više u Gardašević, 2021. 
obzirom na rasu, boju kože, spol, jezik, vjeru, nacionalno ili socijalno podrijetlo”. Također, ni u slučaju neposredne opasnosti za opstanak države ne može se ograničiti primjena odredbi Ustava o pravu na život, zabrani mučenja, surovog ili ponižavajućeg postupanja ili kažnjavanja, o pravnoj određenosti kažnjivih djela i kazni, te o slobodi misli, savjesti i vjeroispovijedi” (st. 3.), što je propisano Europskom konvencijom za zaštitu ljudskih prava i temeljnih sloboda (NN, MU, br. 18/97, $6 / 99,14 / 02,13 / 03,9 / 05,1 / 06,2 / 10)$. Sve dosada navedeno pokazuje da suvremene odredbe Ustava RH eksplicitno ne recipiraju Ciceronovu maksimu o dobrobiti i spasu naroda kao supremae legis. Ciceronovu se maksimu ne smije promatrati izolirano od njegove cjelokupne filozofije i misli koja je dobrim dijelom vezana uz ideju prirodnog prava. Odnosno, iako je vidljiva prisutnost elementa salus populi et rei publicae, u navedenim odredbama uočljiv je manjak još bitnijeg elementa, a to je suprema lex. Jer Ciceron zagovara mogućnost legitimacije iskoraka izvan prava, dajući ovlasti egzekutivi koje ne moraju biti dodatno pravdane i regulirane pozitivnim propisima. Upravo s obzirom na navedeni historijski kontekst i krizne prilike ugroze Republike Ciceronovu maksimu i ovlasti viših magistrata (konzula) treba interpretativno pojmiti mnogo šire od jednodimenzionalnog viđenja svakodnevnog obavljanja državničke dužnosti radi dobrobiti naroda, odnosno republike. U tom je pogledu zanimljivo kako tumačiti ograničenja koja nameće st. 3. čl. 17. u odnosu na Ciceronovu misao?

U vrijeme kad je i sam bio konzul, u svojim Govorima protiv Katiline (Orationes in Catilinam), čija je urota predstavljala ozbiljnu ugrozu za opstojnost Republike, Ciceron sintagmu salus populi/rei publicae stavlja upravo u kontekst spasa naroda $i$ države od pošasti takve vrste općenito. Ciceron ističe kako "ne smije prečesto najviše dobro države doći u opasnost od jednog čovjeka" (Ciceron, 2016, str. 55) te kako će on poduzeti sve što je potrebno za "vrhovni interes države te život i spas (salutem) svih (opći spas)” (ibid., str. 59). Iako je veleizdaja u Rimskoj republici bila kažnjiva smrću (Leges maiestatis), Ciceron javno zagovaranje umorstva Katiline radi spasa Republike pokušava dodatno opravdati prirodnopravnim temeljima (suprema lex). Ciceronova ideja prirodnog prava dobrim se dijelom bazira na vrlinama, pa tako i sam Ciceron pri zagovaranju umorstva Katiline ističe kako se vrlinom treba smatrati takva dužnost da se tirani, ali i druge osobe koje ugrožavaju narod i Republiku, "iskorijene iz ljudskog društva" (Ciceron, 2006, str. 151) te kako nije protivno Prirodi "oteti od onoga koga je pravo i ubiti a uopće sav taj pogubni i bezbožni soj ljudi iz ljudske zajednice... posve iskorijeniti” (ibid.). Kada ne bismo fiktivno primijenili tako postavljen Ciceronov prirodnopravni temelj spasa republike, tada Katilinino umorstvo u današnjim prilikama ne bi bilo moguće zbog st. 3 . čl. 17. U tom trenutku salus rei publicae više nije suprema lex, već samo lex jer je eksplicitno reguliran i u sebi (pozitivistički) isključuje postojanje bilo kojeg drugog 
entiteta, poput vrlina o kojima govori Ciceron i koje su bitan element Ciceronove prirodnopravne ideje, detaljno analizirane prije svega u Dužnostima. Pravo je pitanje također kako tu odredbu Ustava staviti u kontekst problematike terorizma? Je li život jedne ili skupine osoba s terorističkim ciljevima važniji od sigurnosti države i njezinih građana ili je pak, utilitaristički gledajući, obrnuto, što je upravo ono za što se zalagao Ciceron kod umorstva Katiline? Je li moguće djelovati "protiv sile bez sile"?22 Je li ovdje čl. 17. dostatan? Nije nezamislivo da bi sam Predsjednik u uvjetima predviđenima st. 1. čl. 17. mogao doći u situaciju u kojoj je potrebna hitna reakcija (primjerice određena velika talačka kriza), što bi moglo dovesti do djelovanja izvan prava. Vaganje između st. 3. i salutis populi et rei publicae kao supremae legis u tom je slučaju izravna invokacija Ciceronove maksime, a vrlo vjerojatno i njezina konačna primjena.

Prema čl. 101.

Za vrijeme trajanja ratnog stanja Predsjednik Republike može donositi uredbe sa zakonskom snagom na temelju i u okviru ovlasti koje je dobio od Hrvatskoga sabora. Ako Hrvatski sabor nije u zasjedanju, Predsjednik Republike ima ovlast da uredbama sa zakonskom snagom uređuje sva pitanja koja zahtijeva ratno stanje.

U slučaju neposredne ugroženosti neovisnosti, jedinstvenosti i opstojnosti države, ili kad su tijela državne vlasti onemogućena da redovito obavljaju svoje ustavne dužnosti, Predsjednik Republike može, na prijedlog predsjednika Vlade i uz njegov supotpis, donositi uredbe sa zakonskom snagom.

Predsjednik Republike podnijet će uredbe sa zakonskom snagom na potvrdu Hrvatskom saboru čim se bude mogao sastati.

Ako Predsjednik Republike ne podnese uredbu Hrvatskom saboru na potvrdu u skladu sa stavkom 3. ovoga članka ili Hrvatski sabor istu ne potvrdi, uredba sa zakonskom snagom prestaje važiti.

U slučaju iz stavka 1. i 2. ovoga članka Predsjednik Republike ima pravo sazvati sjednicu Vlade i predsjedavati tako sazvanoj sjednici Vlade.

Očito je kako navedeni članak koji reflektira "paralelne ovlasti Hrvatskog sabora s jedne strane te Predsjednika Republike i predsjednika Vlade s druge strane" (Gardašević, 2014, str. 467) ne recipira Ciceronovu maksimu, već upravo senatus consultum ultimum. Međutim, novija je hrvatska ustavna povijest ipak zabilježila slučajeve koji invociraju izvan-pravno djelovanje Predsjednika u izvanrednim stanjima. Rješenjem USRH-a iz 1992. (U-I-179/1991. od 24. lipnja 1992., NN, br. 49/92) meritorno je odlučeno o ustavnosti tridesetak predsjedničkih ratnih uredbi.

22 Pogledati primjerice koncept "rata protiv terorizma" u Gardašević (2011). S druge strane, za rješenje navedenog Ciceronovog pitanja o djelovanju "silom protiv sile" koje ide u drugačijem, neutilitarističkom smjeru vidjeti Webel (2011, str. 29). 
U navedenoj odluci USRH ističe kako pravo Predsjednika iz čl. 101. koje mu daje Ustav u izvanrednim okolnostima "nije ničim ograničeno" te kako Predsjednik "samostalno odlučuje ${ }^{23}$ jesu li se stekle okolnosti koje znače neposrednu ugroženost neovisnosti i jedinstvenosti RH". Naime, hrvatski Ustav iz 1990. (NN, br. 56/90; usp. čl. 17., 101.) uistinu jest davao veće ovlasti ${ }^{24}$ Predsjedniku u izvanrednim stanjima u odnosu na sadašnje odredbe, ali navedena je odluka USRH zasnovana na krivo protumačenoj činjenici kako tadašnja ovlaštenja emaniraju iz sličnosti hrvatskog Ustava s Ustavom francuske Pete Republike (s izmjenama i dopunama iz 1960., 1962., 1963., 1974., 1976. i 1992. godine; Padjen, 1996; vidjeti i Omejec, 1996). Padjen navodi kako se Ustavni sud nije vodio francuskim ustavnim odredbama, ${ }^{25}$ već čak onim weimarskim iz 1919., točnije čl. 48. koji "određuje da Predsjednik Reicha, kad su javna sigurnost i red ozbiljno narušeni unutar Reicha, može poduzeti mjere koje su nužne za njihovo ponovno uspostavljanje, po potrebi uz pomoć oružanih snaga; u tu svrhu ovlašten je da privremeno ukine u cijelosti ili dijelom temeljna prava zajamčena Ustavom Reicha u pogledu osobne slobode, nepovredivosti stana, tajnosti dopisivanja, slobode izražavanja, prava dogovora i udruživanja, te vlasništva" (Padjen, 1996, str. 163). Posebnost čina contra constitutionem osobito se ogleda u činjenici što je Sabor bio u sazivu, odnosno mogao se sastati (Gardašević, 2014, str. 475), iako je naposljetku potvrdio navedene Uredbe.

${ }^{23}$ Pogledati poznate predmete Vrhovnog suda SAD-a Prize Cases i The Protector o postojanju ratnog stanja bez prethodne kongresne objave kao i Lincolnovo obrazloženje takvog akta supremae legis poradi zaštite salutis populi et rei publicae iskorištenog u Američkom građanskom ratu (Gardašević, 2014, str. 28).

24 "Predsjednik Republike donosi uredbe sa zakonskom snagom i poduzima izvanredne mjere u slučaju ratnog stanja ili neposredne ugroženosti neovisnosti i jedinstvenosti Republike, ili kad su tijela državne vlasti onemogućena da redovito obavljaju ustavne dužnosti. Dok se predsjednik Republike koristi tim ovlastima, Zastupnički dom ne može biti raspušten.

Predsjednik Republike podnijet će uredbe sa zakonskom snagom na potvrdu Zastupničkomu domu Sabora Republike Hrvatske čim se Sabor bude mogao sastati."

${ }^{25}$ Analizirajući današnje odredbe francuskog ustava, uistinu se uviđa da su ovlasti predsjednika veće, ali da su ograničene ustavom. Prema čl. 16. francuskog Ustava (Constitution française du 4 octobre 1958) predsjednik države ovlašten je poduzeti sve mjere potrebne s obzirom na okolnosti ugroze "institucija Republike, neovisnosti nacije, integriteta njezinog teritorija ili ispunjenja međunarodnih obveza i neposredne prijetnje, i prekida pravilnog funkcioniranja ustavnih javnih vlasti”. Nakon trideset dana primjene navedenih hitnih ovlasti predsjednik Nacionalne skupštine, Predsjednik Senata, šezdeset članova Nacionalne skupštine ili šezdeset senatora mogu uputiti Ustavnom vijeću predmet kako bi se odlučilo jesu li ti uvjeti još uvijek primjenjivi. Čl. 16. predstavlja izvorni ustavni institut jer su ovlasti izravno regulirane ustavom (Gardašević, 2014, str. 233). Sokol (1997, str. 115) navodi kako su ovlasti predsjednika Francuske za vrijeme izvanrednih stanja gotovo neograničene (no ipak određena ograničenja postoje, primjerice nemogućnost raspuštanja Nacionalne skupštine) i kako mu se daju s ciljem omogućavanja javnim vlastima da u što kraćem roku obavljaju vlastitu zadaću. 


\section{Zaključna razmatranja}

Ciceronova državno(političko)-pravna filozofija, primarno elaborirana u Državi i Zakonima, svojevrstan je odgovor na kontroverzna pitanja i prilike nastale u kriznom posljednjem stoljeću Rimske republike. Iskrivljeni sustav moralnih vrijednosti u rimskom političkom životu, gdje se stječe dojam o potpunom zanemarivanju dobra naroda i Republike u korist vlastite dobrobiti od pojedinih najviših dužnosnika Rimske republike, Ciceronu je dao veliku motivaciju da vlastitim filozofskim i političkim (javnim) djelom doprinese ideji o sigurnosti i opstojnosti Rimske republike. Tako u trećoj knjizi Zakona Ciceron iznosi tvrdnju kako višim magistratima i izvršnoj vlasti vrhovni zakon treba biti upravo dobrobit naroda (ollis salus populi suprema lex esto).

Ciceronovo viđenje supremacije dobrobiti naroda neodvojivo je od njegovog shvaćanja države (rei publicae) kao prirodne zajednice ljudskog bića vođene idejama pravednosti i zajedničke koristi (utilitas communione). Izvršna vlast sve svoje radnje mora primarno poduzimati radi dobrobiti naroda i države, osobito u vrijeme izvanrednih situacija i prijetnji za opstojnost države, gdje se spas države (salus rei publicae), odnosno spas naroda (salus populi) nameće kao svrha, ali uz svojevrsno prirodnopravno uvjetovano ograničenje prilikom veće koncentracije i prekoračenja redovnih ovlasti. Takva je prirodnopravna postavka djelovanja izvan prava u izvanrednim stanjima temelj državno-centrističke ideje o nadmoći države (javne stvari naroda) u odnosu na (pozitivno)pravni poredak.

Ponovno oživljenje i aktualnost Ciceronove tvrdnje uzrokovani su pojavom pandemije COVID-19 kao jedne od najvećih prijetnji kolektivnom ljudskom zdravlju u novijoj povijesti, koja je sa sobom donijela određena ograničavanja ljudskih prava i sloboda. Analiza čl. 16., 17. i 101. Ustava RH u kontekstu COVID-19, ali i zasebna, pokazala je da ostavština Ciceronove maksime, kao djelovanje izvan prava, nije eksplicitno prisutna u hrvatskim ustavnopravnim odredbama. No invociranje Ciceronove maksime u odnosu na navedene članke ipak je otvorilo određena zanimljiva pitanja. Tako se, iako se čl. 16. ne odnosi na izvanredna stanja, već isključivo na pozitivističko (zakonsko) ograničavanje prava i sloboda, pokazalo upravo kako su određene dvojbe povezane s legitimnim ciljevima ograničavanja. Potonje se osobito odnosi na tumačenje pojma "pravnog poretka" koji stoji "bok uz bok" pojmu "javnog morala", što predstavlja svojevrstan odmak od pozitivističkih težnji te vrlo lako može voditi do prilično nekoherentnog tumačenja koje možebitno izlazi iz sfere prava. Također se pokušalo ukazati na mnogoznačnost pojma (javnog) "zdravlja", čije tumačenje također može biti prilično dvojbeno, osobito u kontekstu pandemije COVID-19. Primjer koji je ponuđen u vezi s tim jest aktualno pitanje obveznog cijepljenja koje, doduše, tendira zaštiti javnog zdravlja, ali ipak ne invo- 
cira Ciceronovu maksimu jer je na to pitanje, što je i kazuistički pokazano, itekako primjenjivo načelo razmjernosti.

Po pitanju izvanrednih stanja, analiza čl. 17. i čl. 101., u okviru Ciceronove maksime koja u istima eksplicite nije sadržana, također je dovela do zanimljivih zaključaka. Čl. 17. eo ipso ne invocira Ciceronovu maksimu, naročito u odnosu na st. 3. gdje se situacija oko Katilinine urote pokušala, hipotetski, primijeniti u današnjim uvjetima. St. 3. automatski isključuje kategoriju supremae legis, no zanimljivo je kako bi se to manifestiralo u kontekstu određenih terorističkih pojavnih oblika. Bi li kod tog pitanja, u određenim slučajevima, moglo doći do invokacije iste maksime? Tako je i u okviru čl. 101. kazuistički pokazano kako je tek nedavna hrvatska ustavnopravna povijest ponudila određena izvan-pravna djelovanja koja, doduše implicitno, invociraju upravo Ciceronovu maksimu.

\section{LITERATURA}

\section{Knjige i članci}

Aristotel. (1984). Politika. Beogradski izdavačko-grafički zavod. Beograd.

Arndt, A. (1962). Demokratie - Wertesystem des Rechts. U: Arndt, Adolf(ur.). Notstandsgesetz - aber wie? Köln. str. 7-66.

Asmis, E. (2005). A New Kind of Model: Cicero's Roman Constitution in "De republica". The American Journal of Philology, 126 (3): 377-416.

Aßländer, M. S. (2013). Honorableness or Beneficialness? Cicero on Natural Law, Virtues, Glory, and (Corporate) Reputation. Journal of Business Ethics, 116: 751-767. DOI: $10.1007 / \mathrm{s} 10551-013-1819-7$

Baccarini, E. (2006). Provedba morala putem zakona. Politička misao, 43 (3): 19-37.

Bautista-Valarezo, E. et al. (2020). Towards an indigenous definition of health: an explorative study to understand the indigenous Ecuadorian people's health and illness concepts. International Journal for Equity in Health, 19: 101. DOI: https://doi. org/10.1186/s12939-020-1142-8

Beard, M. (2018). SPQR - povijest starog Rima. Školska knjiga. Zagreb.

Beauchamp, T. L. i Childress, J. F. (2013). Principles of Biomedical Ethics. Oxford University Press. Oxford.

Bircher, J. (2005). Towards a dynamic definition of health and disease. Medicine, Health Care and Philosophy, 8: 335-341. DOI: 10.1007/s11019-005-0538-y

Brennan, C. (2001). The praetorship in the Roman republic. Oxford University Press. Oxford. 
Brown, E. (2009). The Emergence of Natural Law and the Cosmopolis. U: Salkever, S. (ur.). The Cambridge Companion to Ancient Greek Political Thought. Cambridge University Press. Cambridge. str. 331-364. DOI: 10.1017/CCOL9780521867535.013

Ciceron. (1995). Libri politici. Država. Demetra. Zagreb.

Ciceron. (1996). Libri politici. Zakoni. Demetra. Zagreb.

Ciceron. (2002). O govorniku. Matica hrvatska. Zagreb.

Ciceron. (2006). O dužnostima. Nova akropola. Zagreb.

Ciceron. (2016). Govori protiv Katiline. Latina et Graeca. Zagreb.

Dicey, A. V. (1959). Introduction to the Study of the Law of the Constitution. 10. izd. Macmillan. London.

Dyck, A. R. (2004). A Commentary on Cicero. De Legibus. The University of Michigan Press. Ann Arbor.

Fontanella, F. (2013). Politica e diritto naturale nel De legibus di Cicerone. Edizioni di storia e letteratura. Rim.

Friedrich, C. J. (1968). Constitutional Government and Democracy - Theory and Practice in Europe and America. 4. izd. Blaisdell Publishing Company. Waltham, MA.

Friedrich, C. J. (2012). Constitutional Reason of State: The Survival of the Constitutional Order. Literary Licensing, LLC. Whitefish, MT.

Gardašević, Đ. (2011). Američki egzekutivni unilateralizam i "rat protiv terorizma". Zbornik Pravnog fakulteta u Zagrebu, 61 (4): 1295-1337.

Gardašević, Đ. (2014). Ograničenja ljudskih prava i temeljnih sloboda u izvanrednim stanjima. Hrvatska udruga za ustavno pravo. Zagreb.

Gardašević, Đ. (2020). Pandemija i Ustav Republike Hrvatske. Informator, br. 6623, 20. travnja.

Gardašević, Đ. (2021). Pandemija kao stanje velike prirodne nepogode i Ustav Republike Hrvatske. U: Barbić, Jakša (ur.). Primjena prava za vrijeme pandemije COVID-19. str. 23-47. HAZU. Zagreb.

Gross, O. i Ní Aoláin, F. (2006). Law in Times of Crisis: Emergency Powers in Theory and Practice. Cambridge University Press. Cambridge.

Guastini, R. (2016). Sintaksa prava. Naklada Breza. Zagreb.

Gugg, K. H. (1998). Ciceron. U: Maier, H., Rausch, H. i Denzer, H. (ur.). Klasici političkog mišljenja. Knjiga prva. Golden marketing. Zagreb. str. 65-88.

Harries, J. (2016). Servius, Cicero and the Res Publica of Justinian. U: Du Plessis, P. J. (ur.). Cicero's Law. Rethinking Roman Law of the Late Republic. Edinburgh University Press. Edinburgh. str. 123-145.

Helfand, W. H., Lazarus, J. i Theerman, P. (2001). "Salus Populi Suprema Lex": The Health of the People is the Supreme Law. American Journal of Public Health, 91 (5): 689 . 
Herring, J. (2016). Medical Law and Ethics. Oxford University Press. Oxford.

Hobbes, T. (2013). Levijatan. Naklada Jesenski i Turk. Zagreb.

Hornblower, S. i Spawforth, A. (2012). The Oxford Classical Dictionary. 4. izd. Oxford University Press. Oxford.

Jakab, A. (2005). German Constitutional Law and Doctrine on State of Emergency Paradigms and Dilemmas of a Traditional (Continental) Discourse. German Law Journal, 7 (5): 453-477.

Kelsen, H. (1925). Allgemeine Staatslehre. Julius Springer. Berlin.

Koja, F. (1979). Der Staatsnotstand als Rechtsbegriff. Pustet. Salzburg.

Lauc, Z. (2016). Moralitet, legitimitet, legalitet. Zbirka radova. Pravni fakultet Sveučilišta J.J. Strossmayera u Osijeku. Osijek.

Locke, J. (2013). Dvije rasprave o vladi. Naklada Jurčić. Zagreb.

Lohff, B. (2001). Self-healing forces and concepts of health and disease. A historical discourse. Theoretical Medicine, 22: 543-564. DOI: 10.1023/A:1014467523084

Lučić, Z. (2006). Ciceron i prirodno pravo. Pravni fakultet Univerziteta u Sarajevu. Sarajevo.

Mantovani, D. (2016). More than Codes. Roman Ways of Organising and Giving Access to Legal Information. U: Du Plessis, P. J., Ando, C. i Tuori, K. (ur.). The Oxford Handbook of Roman Law and Society. Oxford University Press. Oxford. str. 23-43.

Moots, G. i Forster, G. (2010). Salus populi suprema lex: John Locke Versus Contemporary Democratic Theory. Perspectives on Political Science, siječanj-ožujak, 39 (1): 35-45. DOI: https://doi.org/10.1080/10457090903455754

Omejec, J. (1996). Ograničavanje sloboda i prava čovjeka i građanina u izvanrednim stanjima. Društvena istraživanja, 5 (2 (22)): 345-376.

Padjen, I. (1996). Uredbe iz nužde hrvatskog predsjednika: mjerodavnost francuskog javnog prava. Politička misao, 33 (1): 149-165.

Petrak, M. (2010). Traditio iuridica. Vol. 1. Regulae Iuris. Novi informator. Zagreb.

Pina Polo, F. (2016). SPQR. Institutions and Popular Participation in the Roman Republic. U: Du Plessis, P. J., Ando, C. i Tuori, K. (ur.). The Oxford Handbook of Roman Law and Society. Oxford University Press. Oxford. str. 85-98.

Platon. (1982). Odbrana Sokratova. Kriton. Fedon. Beogradski izdavačko-grafički zavod. Beograd.

Platon. (2001). Država. Naklada Jurčić. Zagreb.

Romac, A. (1983). Rječnik rimskog prava. Informator. Zagreb.

Rossiter, C. (2011). Constitutional Dictatorship - Crisis Government in the Modern Democracies. Rossiter Press.

Schmitt, C. (2019). Politička teologija / Politička teologija II. Naklada Breza. Zagreb. 
Scheuner, U. (1950). Der Verfassungsschutz im Bonner Grundgesetz. U: Um Recht und Gerechtigkeit: Festgabe für Erich Kaufmann. str. 318-320.

Sellers, M. (2009). The Influence of Marcus Tullius Cicero on Modern Legal and Political Ideas. Ciceroniana On Line. Atti del XIII Colloquium Tullianum (Milano, 27-29 marzo 2008). Vol. 13. DOI: 10.13135/2532-5353/1446

Smith, G. B. (2018). Political Philosophy and the Republican Future. Reconsidering Cicero. University of Notre Dame Press. Notre Dame, Indiana.

Sokol, S. (1997). Temeljna obilježja Francuskog ustava iz godine 1958. Vladavina prava, 1 (4-5-6): 113-148.

Sokol, S. i Smerdel, B. (2009). Ustavno pravo. Narodne novine. Zagreb.

Stein, P. (2007). Rimsko pravo i Europa. Povijest jedne pravne kulture. Golden marketing. Zagreb.

Stern, K. (1980). Das Staatsrecht der Bundesrepublik Deutschland. C. H. Beck. München.

Stojčević, D. i Romac, A. (1971). Dicta et regulae iuris. Savremena administracija. Beograd.

Straumann, B. (2011). Constitutional thought in the late Roman republic. History of Political Thought, 32 (2): 280-292.

Straumann, B. (2015). Roman Law in the State of Nature. The Classical Foundations of Hugo Grotius'Natural Law. Cambridge University Press. Cambridge.

Vervaet, F. J. (2016). Magistrates Who Made and Applied the Law. U: Du Plessis, P. J., Ando, C. i Tuori, K. (ur.). The Oxford Handbook of Roman Law and Society. Oxford University Press. Oxford. str. 219-234.

Von Jhering, R. (1923). Der Zweck im Recht. 6-8. izd. 2 sv. Breitkopf \& Härtel. Leipzig.

Walker Keyes, C. (1921). Original Elements in Cicero's Ideal Constitution. The American Journal of Philology, 42 (4): 309-323.

Webel, C. P. (2011). The Ethics of Terror and Terrorism. U: Webel, C. P. i Arnaldi, J. A. (ur.). The Ethics and Efficacy of the Global War on Terrorism. Fighting Terror with Terror. Palgrave Macmillan. New York. str. 29-45.

Wood, N. (1988). Cicero's Social and Political Thought. University of California Press. Berkeley.

\section{Pravni akti}

Europska konvencija za zaštitu ljudskih prava i temeljnih sloboda. NN, MU, br. 18/97, 6/99, 14/02, 13/03, 9/05, 1/06, 2/10.

ESLJP(Europski sud za ljudska prava). Vavřička i drugi protiv Češke, 47621/13, 3867/14, 73094/14 et al., od 8. travnja 2021.

Grundgesetz für die Bundesrepublik Deutschland. Bundesgesetzblatt Teil III, Gliederungsnummer 100-1. 
Kazneni zakon. NN, br. 125/11, 144/12, 56/15, 61/15, 101/17, 118/18, 126/19.

Legge n. 225 del 24 febbraio 1992: istituzione del Servizio Nazionale della Protezione Civile. Pubblicata nella Gazzetta Ufficiale n. 64 del 17 marzo 1992.

Magyarország Alaptörvénye. 2011. Constitution of the Republic of Hungary.

Odluka USRH broj: U-IIIB-3173/2012 od 18. ožujka 2014.

Odluka USRH broj: U-II-2379/2020 od 14. rujna 2019. i tri izdvojena mišljenja sudaca.

Prijedlog Peđe Grbina za pokretanje postupka za ocjenu suglasnosti s Ustavom, s člancima 10., 13., 14. i 18. ZIDZZP-a/20, predmet broj: U-I-2075/2020.

Rješenje USRH broj: U-I-1372/2020 i dr. od 14. rujna 2020. i pet izdvojenih mišljenja sudaca.

Rješenje USRH broj: U-I-179/1991 od 24. lipnja 1992. NN, br. 49/92.

Texte intégral de la Constitution du 4 octobre 1958 en vigueur.

UN. Međunarodni pakt o ekonomskim, socijalnim i kulturnim pravima. 1966. NN, MU, br. $12 / 93$.

UN. CESCR. General Comment No. 14: The Right to the Highest Attainable Standard of Health (Art. 12 of the Covenant). 11 August 2000. E/C.12/2000/4.

Ustav Republike Hrvatske. NN, br. 56/90, 135/97, 8/98, 113/00, 124/00, 28/01, 41/01, 55/01, 76/10, 85/10, 5/14.

Zakon o izmjenama i dopunama Zakona o sustavu civilne zaštite. NN, br. 31/20.

Zakon o izmjenama i dopunama Zakona o zaštiti pučanstva od zaraznih bolesti. NN, br. $47 / 20$.

Zakon o sustavu civilne zaštite. NN, br. 82/15, 118/18, 31/20.

Zakon o ublažavanju i uklanjanju posljedica prirodnih nepogoda. NN, br. 16/19.

Zakon o zaštiti pučanstva od zaraznih bolesti. NN, br. 79/07, 113/08, 43/09, 130/17, $114 / 18,47 / 20,134 / 20$. 
Tomislav Nedić

\author{
CONTEMPORARY RECEPTION OF CICERO'S \\ NATURAL LAW POSTULATE ON THE SUPREMACY \\ OF WELL-BEING AND SALVATION OF THE PEOPLE \\ IN THE CONTEXT OF STATES OF EMERGENCY \\ ACTUALIZED BY THE COVID-19 PANDEMIC
}

\begin{abstract}
Summary
The work offers an interpretive analysis and reception of Cicero's claim about the imperative supremacy of welfare and salvation of the people (salus populi suprema lex esto), made in the third book of Cicero's Laws. This statement is only a piece of the "puzzle" of Cicero's reflections on government laws, largely focused on the reparation and survival of the Roman Republic, the historical context of which displays many adversities afflicting its integrity. First of all, it is necessary to offer an interpretive overview of Cicero's claim about the supremacy of welfare and salvation of the people and the Republic in the historical context of the Roman political and legal circumstances, in order to gain a complete insight into the reception of the claim, especially in legal doctrine and practice. The actuality of Cicero's claim in the form of constitutional provisions (Articles 16, 17 and 101 of the Constitution of the Republic of Croatia) on states of emergency and crisis has particular relevance against the backdrop of the COVID-19 pandemic, but also for some new controversies, as demonstrated by the case study of recent decisions taken by the Constitutional Court of the Republic of Croatia.

Keywords: Cicero, Salus Populi, Suprema Lex, Constitution, Natural Law, Res Publica, COVID-19
\end{abstract}

Tomislav Nedić asistent je na Akademiji za umjetnost i kulturu Sveučilišta J.J. Strossmayera u Osijeku i doktorski student na doktorskom studiju prava Pravnog fakulteta Sveučilišta J.J. Strossmayera u Osijeku.

Kontakt: Tomislav Nedić, Akademija za umjetnost i kulturu Sveučilišta J.J. Strossmayera u Osijeku, Trg Svetog Trojstva 3, 31000 Osijek. E-mail: nedict@gmail.com 